\title{
Péter Várkonyi
}

Kompolt: The Divided Village

Pro\&Contra

1 (2018) 81-95. 



\begin{abstract}
This paper discusses the history of modern Kompolt, a village in Heves County, Hungary, with a particular emphasis on its social history. During the $19^{\text {th }}$ and $20^{\text {th }}$ centuries, the society of Kompolt was split along a number of lines and this essay focuses on just one of these divisions, that between the Swabians and the Hungarians.
\end{abstract}

Keywords: Kompolt, identity, Germans, Swabians, Hungarians, society, $19^{\text {th }}$ century, $20^{\text {th }}$ century, immigrants, agriculture, material culture, demography

\title{
I. Hypothesis
}

This research is grounded in a paradox. ${ }^{1}$ Swabians have resided in Kompolt since the $18^{\text {th }}$ century but the statistics (for example, the censuses from the $20^{\text {th }}$ century) do not reflect this ethnic reality.

A detailed examination can uncover the reason for this paradox. The settlement structure and material culture (on maps and in today's reality), the sources of Kompolt's economic status, and the self-reflections of the inhabitants (in the personal papers of both the town's inhabitants and the community, as well as in interviews) confirm that Kompolt was indeed divided in the past and thus brings the accuracy of the censuses into question. It is this disconnect between reality and bureaucracy that supplies the hypothesis for this study.

The prime importance of source criticism for the result of censuses is widely accepted. The methodology ${ }^{2}$ adopted, the assessors and external factors (politics ${ }^{3}$, indiscretion $^{4}$, and beliefs ${ }^{5}$ ) affect the comparability and usability of the results of censuses. So, if an accurate view of the ethnic situation of the country is to be provided, a micro-level approach is needed. Failing this, some groups in society and certain of their characteristics will remain hidden.

1 The author's first research was supported by the grant EFOP-3.6.1-16-2016-00001 (“Complex improvement of research capacities and services at Eszterházy Károly University").

2 Gábor Gyáni and György Kövér, Magyarország társadalomtörténete a reformkortól a második világháborúig (Budapest: Osiris, 2001), 145, 151.

3 Ágnes Deák, Polgári átalakulás és neoabszolutižmus 1849-1867 (Budapest, Kossuth, 2009), 23.

4 Zoltán Czibulka and Ervin Heinz and Miklós Lakatos, A magyarországi németek kitelepitése és az 1941. évi népszámlálás (Budapest, KSH, 2004).

5 Györgyi Bindorffer, “»nem tudok jól magyarul, de magyar vagyok, mert ez az én hazám...« A hazaszeretet megnyilvánulása Véménden,” Kisebbségkutatás 13, no. 4 (2004): 556. 
Of course, it is impossible to examine every settlement in this way, but case studies can be conducted so as to illuminate the issues. The main purpose of this text is to attempt to present a method for complex and micro-level research which can help clarify and amend the results of the censuses so that a more realistic picture of this town's society can be provided.

\section{The method}

First, it is important to examine the society of Kompolt from several viewpoints: the origins of the inhabitants, the distinctiveness of the material culture, the economic status, the connections between identity and demography, as well as the distribution of power.

The diversity of the characteristics outlined above requires a variety of methods as well. The information of the inhabitants' origins come from archival sources and collective memory (elements of which have been collected through structured and unstructured interviews). The examination of the material culture in Kompolt is limited because there was no complete, unique folk culture in the village. Only the built culture and burial habits display peculiarities. The fieldwork undertaken has been supported and informed by the literature.

The statistical analysis of the cadastres gives a detailed image of the inhabitants' economic status and can clarify the connections between identity and demography. The protocols of the council refer to the traditions of power distribution in Kompolt.

This method is a mixture of the etic and emic approach. The contemporary definitions and categories are applied but because of the temporal distance and the historical perspective the fashioned concept is necessarily distorted. ${ }^{6}$

\section{Origin}

After a rich medieval history, Kompolt was abandoned in the $16^{\text {th }}$ century due to the Ottoman conquest. 200 years later, a Hungarian nobleman, Antal Grassalkovich, bought the estate, had a castle built in the Baroque style and repopulated the settlement. ${ }^{7}$ In 1754 several Hungarian and 100 German-speaking families moved into the village. These two distinct ethnic groups became the basis of the division which determined the modern history of Kompolt. ${ }^{8}$

6 Henriett Primecz, "Étikus és émikus kultúrakutatások," in Vezetéstudomány 37, Spec. issue no. 2 (2006): 4-5.

Gábor Éble, A debröi uradalom birtoklási története (Budapest: Pfeifer Ferdinánd, 1909), 17.

$8 \quad$ Imre Soós, Heves megye községei 1867-ig (Eger, 1975), 331.

Pro\&Contra 1 (2018) 74-87. 
The Hungarians became agricultural laborers on the estate, the Swabians (this is the accepted name of the German-speaking settlers) were self-employed farmers with their own land. Grassalkovich's idea was to establish two social factions-a group of low-paid laborers and a group of experienced farmers. Thanks to the Swabians, the more developed Western-European work culture was adopted in the village. Due to it being advantageous for the Grassalkovich manor, the new settlers from German territory received tax exemptions and building materials. ${ }^{9}$

German-speaking people were settled by Grassalkovich in a neighboring village (Aldebrô) too, but in this region of the country there were no large areas inhabited by German settlers. The personal and economic connections between Kompolt and Aldebrő were not significant. ${ }^{10}$

According to the written sources, the German-speaking settlers came from Alsace. The oral tradition refers to multiple areas and years. The village elders refer to three waves, 1754 being the year of the third wave. ${ }^{11}$ During his research, Ferenc Bakó attempted to determine the dates of earlier arrivals. According to him, there were two colonizations, in 1747 and 1748. According to oral tradition, the areas from which they originated were Köln and The Low Countries. ${ }^{12}$

The origin of the Hungarian settlers is unknown. This phenomenon also shows that roots were more important for the German-speaking community and for the researchers, the Hungarians were relegated to the background from the very beginning. As a result of the Hungarians' existential deficit, the society of Kompolt remained divided in multiple ways up until the middle of the $20^{\text {th }}$ century.

9 Imre Soós, Az egri egyházmegyei plébániák történetének áttekintése (Budapest: Szent István Társulat, 1985), 227.

10 According to the registers and the memoirs.

11 From an interview with Mrs. I. H.

12 Ferenc Bakó, “Kompolt község településnéprajzának vázlata,” in Néprajzi tanulmányok Ikvai Nándor emlékére I. (Studio comitatensia 23.), ed. László Novák (Szentendre: Pest Megyei Múzeumok Igazgatósága, 1994), 174. 


\section{Material Culture}

From the perspective of the $21^{\text {st }}$ century, the most outstanding difference between the Hungarians and Swabians in the $19^{\text {th }}$ century was the space allocation in the village. During the time under investigation, Kompolt essentially consisted of two streets and a center. The church and the castle were built in the centre. The houses of the Swabians were built south of the center, the name of which indicates its importance, it was called the "Falu" (meaning "village"). The name suggests that it was the "real" core of Kompolt. ${ }^{13}$ The other street was known as the "Sor" (meaning "line," because originally there were houses on one side of the street forming a line). The "Sor" was located north of the castle; the houses of the Hungarians were located here.

All public institutions and services were in the "Falu:" the city hall, the school, the community center, the cemetery, the shop, and the tavern. (In 1895 there were four licensed liquor stores in the "Falu.") Local craftsmen were mostly Swabians too, their workshops were found in the "Falu," at the angles of its two ends, whereas in the "Sor" there were no services, except for some illegal pubs. Thus, when a resident from the "Sor" wanted to have fun, learn, or arrange a case, he had to go to the "Falu."

This different financial status led to conspicuous differences in material culture. Sites with 3-4 houses were typical in both streets. According to the ethnographers, this was either because of mistrust or geographical features. But the sites of the Swabians were bigger and wider than those of the Hungarians. ${ }^{14}$ They owned their own land, they were self-employed, and every Swabian family had a barn for their crops which was typically opposite the house. The houses in the "Falu" were built of stone with greater comforts (for example, wooden flooring and ceramic stoves). ${ }^{15}$

The inhabitants of the "Sor" worked in the manor; they did not need economic buildings, so the sites on the street were narrower. The Hungarians' houses were built from loam, and were more exposed to the floods of the river Tarna.

Originally, the Swabians lived in the "Falu," the Hungarians lived in the "Sor." Over the years some Swabian families fell into poverty, leading to several ethnically heterogeneous marriages. Thanks to these processes, the "Sor" became heterogeneous, but the community of the "Falu" retained its ethnic homogeneity, social mobility, then, was a

13 Bakó, “Kompolt község," 174.

14 Following my field trips.

15 Ferenc Bakó, "Párhuzamok és eltérések az Eger környéki magyarság és a nemzetiségek településében, építkezésében," in Interetnikus kapcsolatok Északkelet-Magyarorsqágon (Az 1984 októberében megrendezett konferencia anyaga) eds. Ernő Kunt, József Szabadfalvi, Gyula Viga (Miskolc: Hermann Ottó Múzeum, 1984), 106. 
one-way movement. ${ }^{16}$ However, the degree of the groups' separation is not clear based on the data of censuses.

Not only was the lifestyle of the residents determined by the described social structure, but so was death. There are many tombstones from this period in the cemetery, but most of the grave markers were erected to commemorate Swabian people. Naturally, the Hungarians also marked the graves of their loved ones, but (because of their poverty) were only able to do so with perishable wooden crosses, a difference with economic roots and not primarily ethnographic. It is noteworthy that all the memories from the past are in one way or another connected to the Swabians. ${ }^{17}$

\section{Economy}

Until the middle of the $20^{\text {th }}$ century, Kompolt was an agricultural settlement. The industrial activity only satisfied the needs of the village. For example, in 1900 the sum of employees of the industrial companies was less than 20, although it grew to 29 in 1910 and 93 in $1920 .{ }^{18}$

Most of the inhabitants worked in the primary sector. The most typical crops were cereals, but the villagers also produced tobacco ${ }^{19}$ and grapes ${ }^{20} .^{21}$ To obtain an accurate picture of the economic sector, we have to use the land registers, especially the registers of the land tax. ${ }^{22}$ As part of my research I have applied the land tax register of the year 1887 and 1911. In 1887 Kompolt's area was 4076 jugerums, a figure which did not change until the 1950s.

16 Vital records at the parish of Kál and cadastres from 1887 and 1911 (National Archives of Hungary - Heves County Archives XV-8/a 282. III/1. 1887.; XV-8/a 282. III/1. 1911.

17 Following my field trips.

18 A Magyar Szent Korona országainak 1910. évi népszámlálása. Szerk. és kiad. A Magyar Királyi Központi Statisztikai Hivatal (Budapest: Atheneum, 1912-1920.) A népesség főbb adatai községek és népesebb puszták, telepek szerint (1912) 184-185.

19 Bakó, "Párhuzamok," 109.

20 Erzsébet Löffler, "Adatok az egri filoxéravész történetéhez," in Az egri Dobó István Vármúzeum évkönyve XX., ed. Sándor Bodó (Eger, 1984), 153.; József Kozári, "Filoxéravész az egri borvidéken,” in Eszterbázy Károly Tanárképzó Föiskola Tudományos Közleményei XIX. Tanulmányok a Történettudomány Köréböl, ed. József Nagy (Eger, 1989), 60.

21 A Magyar Korona orságainak mezógazdasági statisztikája I. A magyar mezőgazdasági statisztika fejlődése és az összeírás főbb eredményei községenkint (Budapest, 1897), 286.

22 Cadastres from 1887 and 1911 (National Archives of Hungary - Heves County Archives XV-8/a 282. III/1. 1887.; XV-8/a 282. III/1. 1911.) 
The historical Kompolt's structure of agriculture differed from the national data. ${ }^{23}$ In 1887 half of the farms were less than 1 jugerum, and the total area of these farms was $1 \%$ of the total area of Kompolt, but $59 \%$ of the land was in the hands of the Lordship of Debrő-Parád, which was the Károlyi estate. (During the 1800s the Károlyi family bought the manor.) At that time only Count Károlyi owned more than 1,000 jugerums in Kompolt.

$49 \%$ of the landowners owned farmland of between 1 and 50 jugerums. Almost none of the farmers had more than 50 jugerums.

According to the national data in $1895,25 \%$ of the farmers owned less than 1 jugerum. Proportionally, in Kompolt there were fewer farmers with 1-5 and 5-100 jugerums than in the whole country. The proportion of the farms between 100 and 200 jugerums was similar to the national average. After comparing the local and national situation it is clear that the class of middle-sized family farms was non-existent in Kompolt making this village poorer than the national average.

The farmers can be categorized into several groups. As already established, the biggest landowner in the village was the Károlyi family, the count owning 59\% of the area. The remaining $41 \%$ consisted of areas owned by the local and state authorities (for example, the municipality, the church, the railway company amongst others) and 290 private farms.

the economic structure was marked by ethnic division too. 210 farmers had German and 80 landowners had Hungarian surnames. 79 Hungarians owned less than 2 jugerums, and that was $98.75 \%$ of the Hungarian landowners. Eighty of the Swabians had less than 2 jugerums, which was $42.68 \%$ of the Swabian farmers. The private farms larger than 5 jugerums were Swabians' without exception and most of the Swabians owned more than 5 jugerums.

In 1887 there were 117 private landowners with a German surname in Kompolt, and they owned 95\% of the private land. The richest farmers were Swabians but among the poorest there were Hungarians and Swabians too. The 72 poorest landowners had nothing but "internal" sites (for example, the house and yard). It is especially important to note that the land registers included only those who had any land in Kompolt. If somebody had sites in other settlements, or he was a craftsman, they are not listed in the cadastres of Kompolt; there was also a landless group in the village which is also not included in this source.

23 Péter Hanák, Ferenc Mucsi, eds. Magyarország története 7/I. (1890-1918.) (Budapest: Akadémiai, 1978), 300. 
The cadastres also allow for research into the quality of the land. ${ }^{24}$ The soils of the Hungarians were "Gyalog legelo"," which were of the worst quality. It was perhaps based on a customary law (maybe on ethnic basis), but there is no source which could prove this theory. The differences of land quality resulted in significant income differences.

Beyond land cultivation, the breeding of livestock was an important sector of agriculture. Without accurate sources the owners of livestock cannot be determined. According to the cadastres, the richest farmers had pastures. In 1911 there were 293 livestock owners in Kompolt. ${ }^{25}$ The most valuable farm animals were cows. The number of cows had stagnated, and at the end of the examined period the proportion of current animal breeds was significant. The villagers also bred horses, mainly German breeds. ${ }^{26}$ The manor had a great herd; moreover, in the 1880s a British stableman worked with the Count's horses. He was called "Ferenc" Robinson. ${ }^{27}$ The number of horses and sheep gradually declined but the proportion of pigs increased-this reflected the national trends of the time. $^{28}$

\section{Identity and Demography}

As stated in the introduction, the focus of this paper is on the ethnic division that existed in Kompoltbutwhich was not recorded in the censuses of the time. Although the censuses from the era show that the Swabians were in a minority in Kompolt, and that those same sources suggest continuous assimilation, other documents, community memory, and contemporary experience identify a group who separated themselves from the Hungarians. These people considered themselves Swabians, but declared themselves Hungarian in the censuses.

24 Heves vármegye adóközségeinek területe és kataszteri tisztajövedelme mivelési áganként és osztályonként. Az 1909. évi V. T.-czikk alapján végrehajtott kataszteri kiigazítás után (Budapest: Magyar Királyi Állami Nyomda, 1913), 5, 10, 42, 44.

25 A Magyar Szent Korona Országainak állatlétszáma az 1911-ike évi február 28-iki állapot szerint. Magyar Statisztikai Közlemények. Új sorozat 41. kötet (Budapest, 1913), 378.

26 Bakó, "Kompolt község," 109.

27 Vital records at the parish of Kál; protocols of the city council 1877-1895 (National Archives of Hungary - Heves County Archives V-248/1)

28 Hanák and Mucsi, "Magyarorsðág története," 329. 
In conclusion, it is clear that censuses are not adequate for the purpose of determining who was Hungarian and who was Swabian. ${ }^{29}$

Marriage was one of the markers of this ethnic division. As outlined above, in Kompolt the wealthy families were Swabians. The coordinates of social value were the residence, the financial status, the position, and the surname. A German surname was necessary but not enough to identify someone as a Swabian; money also played a key role in this demarcation. Based on the analysis of marriages, Swabian-Hungarian inter-marriage was rare. Only the poorer Swabian youngsters chose Hungarian partners. This was the reason for the "Falu" remaining ethnically homogeneous in contrast to the "Sor."

And there is another association. The Swabians' self-image was positive, generally thinking of themselves as hardworking, intelligent, and open-minded people. ${ }^{30}$ From the perspective of the "Falu," the inhabitants of the "Sor" were poor and unschooled. In the light of such attitudes, on the rare occasion of a Swabian-Hungarian marriage, the Hungarian spouse always came from another settlements and not from Kompolt's "Sor." 31 This territorial and social segregation constructed a barrier between the two groups. During the interviews, the informants mentioned that it would be highly unusual for a boy to go courting to the other part of the village than.

Regarding modernization, Kompolt's demographic trends reflected those of the nation (number of children etc.). ${ }^{32}$

Az 1890-iki népszámlálás föbb eredményei vármeg yék és községek szerint Szerk. Jekelfalussy József (Budapest: Pesti Kvny., 1892), 218-219.; A Magyar Korona országainak 1900. évi népszámlálása Szerk. és kiad. A Magyar Királyi Központi Statisztikai Hivatal (Budapest: Pesti Kvny., 1902-1906.) A népesség általános leírása községenkint (1902) 531.; A Magyar Szent Korona országainak 1910. évi népszámlálása Szerk. és kiad. A Magyar Királyi Központi Statisztikai Hivatal (Budapest: Atheneum, 1912-1920.) A népesség főbb adatai községek és népesebb puszták, telepek szerint (1912) 184-185.; Az 1920. évi népszámlálás Szerk. és kiad. A Magyar Királyi Központi Statisztikai Hivatal (Budapest: Pesti Kvny., 1923-1929.) A népesség fóbb demográfiai adatai községek és népesebb puszták, telepek szerint (1923) 82-83.

30 Györgyi Bindorffer, Sztereotipizááió ą interetnikus kapcsolatokban. 1. http://www.mtaki.hu/tanulmanyok/bindorffer_gyorgyi/index.html?a=all

31 Vital records at the parish of Kál.

32 Gyáni and Kövér, “Magyarország társadalomtörténete,” 145, 151. 


\section{Power}

There were significant differences in power, administration and local government too. ${ }^{33}$

Up until 1945 all mayors were Swabian, representing the richer families. In the lists of the local representatives there are only a few Hungarians. The members of the committees were Swabians. In the local administration, the Hungarians worked only as watchmen, guards, etc. ${ }^{34}$

In 1919 during the Hungarian Soviet Republic the situation reversed. All members of the directorate and most council members were Hungarians. Of those with German surnames, it was only the poorest who attained positions on the council, and they were invariably inhabitants of the "Sor." Due to its nature, the new political system was organized not along ethnic lines, but economic ones. ${ }^{35}$ After the fall of the Hungarian Soviet Republic the Swabians returned to power, and the communists were arrested. According to reports, it was deliberate that the magistrates did not help those arrested. ${ }^{36}$

After World War II, the Swabians were removed from the important positions. In those years "only" the soldiers of the Soviet Red Army abused the Swabians. It caused much trauma and extended the already existing differences between Hungarians and Swabians. ${ }^{37}$ The fact that it was only the Swabians who were harassed in Kompolt by the Soviet soldiers indicates that for the Red Army (with the help of a local man) it was clear who was Swabian and who was Hungarian. Because on the occasion of the census of 1941 no one claimed to be German, the deportations to Germany did not affect the village. But more than 70 Swabian people were deported to forced labor to the Soviet Union for years.

\section{Summary}

This paper attempted to reconstruct the social structure of Kompolt. As a result of the research two groups were distinguished: the Swabians and the Hungarians. Differences in economic circumstances, in family life, in the material culture, in the view of history, and in identity can be ascribed to ethnic origins. Such differences did not appear in the national statistics (for example, in the results of the censuses).

33 Protocols of the city council 1877-1950 (National Archives of Hungary - Heves County Archives V-248/1-5, XXII-347/1-2).

34 Vital records at the parish of Kál.

35 Protocols of the city council 1916-1920 (National Archives of Hungary - Heves County Archives $\mathrm{V}-248 / 3)$.

36 Protocols of the city council 1916-1920 (National Archives of Hungary - Heves County Archives $\mathrm{V}-248 / 3)$.

37 Oral history interviews. 
As noted, all events of note from Komplot's past can be linked to the Swabians. The owners of existing houses and tombstones were Swabians, most names in the sources are German, the famous people from the village were Swabians (for example, János Mayer, Kató Hámán, András Hámán, etc.). Hungarians were merely "supporting actors" in the lives of their German neighbors.

Who was Swabian? Who was Hungarian? Swabians were the inhabitants of Kompolt who lived in the part of the village called "Falu," they had a relatively large income and a German surname. These judgements rest on the contemporary ingroup and outgroup local classification evident in the sources. Hungarians were the Hungarian-named settlers and poorer people with or without German names, who lived in the "Sor." Thus, demonstrating that the "Falu" was more closed than the "Sor." This situation of division continued until the middle of the $20^{\text {th }}$ century but in some ways it makes its presence felt even today. It is hoped this research has uncovered the operation of the ethnic groups' identity, especially in relation to concealment and revelation. 


\section{References}

\section{$\underline{\text { Sources }}$}

A Magyar Korona országainak 1900. évi népszámlálása Szerk. és kiad. A Magyar Királyi Központi Statisztikai Hivatal (Budapest: Pesti Kvny., 1902-1906.) A népesség általános leírása községenkint (1902) 531.

A Magyar Korona országainak mezógazdasági statisztikája I. A magyar mezőgazdasági statisztika fejlődése és az összeírás főbb eredményei községenkint (Budapest, 1897), 286.

A Magyar Szent Korona országainak 1910. évi népszámlálása. Szerk. és kiad. A Magyar Királyi Központi Statisztikai Hivatal (Budapest: Atheneum, 1912-1920.) A népesség főbb adatai kÖzségek és népesebb puszták, telepek szerint (1912) 184-185.

A Magyar Szent Korona Országainak állatlétszáma az 1911-ik évi február 28-iki állapot szerint. Magyar Statisztikai Közlemények. Új sorozat 41. kötet (Budapest, 1913), 378.

Az 1890-iki népszámlálás fóbb eredményei vármegyék és községek szerint Szerk. Jekelfalussy József (Budapest: Pesti Kvny., 1892), 218-219.

Az 1920. évi népszámlálás Szerk. és kiad. A Magyar Királyi Központi Statisztikai Hivatal (Budapest: Pesti Kvny., 1923-1929.) A népesség főbb demográfiai adatai községek és népesebb puszták, telepek szerint (1923) 82-83.

\section{Field trips.}

Heves vármegye adóközségeinek területe és kataszteri tisztajövedelme mivelési áganként és osztályonként. Az 1909. évi V. T.-czikk alapján végrehajtott kataszteri kiigazítás után (Budapest: Magyar Királyi Állami Nyomda, 1913), 5, 10, 42, 44.

Kompolt's cadastre (1887) (National Archives of Hungary - Heves County Archives XV8/a 282. III/1. 1887.)

Kompolt's cadastre (1911) (National Archives of Hungary - Heves County Archives XV8/a 282. III/1. 1911.)

Oral history interviews.

Protocols of the city council 1877-1950 (National Archives of Hungary - Heves County Archives V-248/1-5, XXII-347/1-2). 
Vital records of Kompolt 1819-1950 (at the parish of Kál).

\section{Bibliography}

Bakó, Ferenc. "Kompolt község településnéprajzának vázlata.” In Néprajzi tanulmányok Ikvai Nándor emlékére I. (Studio comitatensia 23.), edited by László Novák, 173-185. Szentendre: Pest Megyei Múzeumok Igazgatósága, 1994.

Bakó, Ferenc. "Párhuzamok és eltérések az Eger környéki magyarság és a nemzetiségek településében, építkezésében." In Interetnikus kapcsolatok Északkelet-Magyarorságon (Az 1984 októberében megrendezett konferencia anyaga), edited by Ernő Kunt, József Szabadfalvi, Gyula Viga, 103-119. Miskolc: Hermann Ottó Múzeum, 1984.

Bindorffer, Györgyi “"»nem tudok jól magyarul, de magyar vagyok, mert ez az én hazám...« A hazaszeretet megnyilvánulása Véménden.” Kisebbségkutatás 13, no. 4 (2004): 556.

Bindorffer, Györgyi. Sztereotipizáció az interetnikus kapcsolatokban. 1. http:/ /www.mtaki.hu/ tanulmanyok/bindorffer_gyorgyi/index.html?a=all

Czibulka, Zoltán and Heinz, Ervin and Lakatos, Miklós. A magyarorsqági németek kitelepitése és az 1941. évi népszámlálás. Budapest: KSH, 2004.

Deák, Ágnes. Polgári átalakulás és neoabszolutizmus 1849-1867. Budapest: Kossuth, 2009.

Éble, Gábor. A debrôi uradalom birtoklási története. Budapest: Pfeifer Ferdinánd, 1909.

Gyáni, Gábor and György Kövér. Magyarország társadalomtörténete a reformkortól a második világháborúig. Budapest: Osiris, 2001.

Hanák, Péter and Mucsi, Ferenc, eds. Magyarország története 7/I. (1890-1918.) Budapest: Akadémiai, 1978.

Kozári, József. "Filoxéravész az egri borvidéken.” In Eszterházy Károly Tanárképzőo Főiskola Tudományos Közleményei XIX. Tanulmányok a Történettudomány Köréből, edited by József Nagy, 25-44. Eger, 1989.

Löffler, Erzsébet. "Adatok az egri filoxéravész történetéhez." In Az egri Dobó István Vármúzeum évkönyve XX, edited by Sándor Bodó, 147-164. Eger, 1984.

Primecz, Henriett. "Étikus és émikus kultúrakutatások." In Vę̧etéstudomány 37, Spec. issue no. 2 (2006): 4-13. 
Soós, Imre. Az egri egyházmegyei plébániák történetének áttekintése. Budapest: Szent István Társulat, 1985.

Soós, Imre. Heves megye községei 1867-ig. Eger, 1975. 